\title{
The effect of deisopropylngaione on the renal function in sheep
}

\author{
* Ogunsan, E.A., Dogo, G.I. ', **Bannor, T.T. and Ogedengbe, J.D. ${ }^{1}$. \\ *Department of Veterinary Pathology and Public Health, \\ University of Queensland, Brisbane, Queensland, Australia 4067. \\ Department of Parasitology, National Veterinary Research Institute, Vom. \\ *Address of author to whom all correspondences are to be sent [P.O. Box 43 Vom. Plateau State] \\ ** Present Address is P.O. Box AH 301 Achimota, Ghana
}

\begin{abstract}
Following intoxication of sheep with $150 \mathrm{mg} / \mathrm{kg}$ body weight of Deisopropylngaione [DIN] intra-peritoneally, there was impairment of the renal function as depicted by decreases in the glomerular filtration rate [GFR], renal plasma flow [RPF] and tubular transport maximum for glucose [TMG] which were essentially pre-renal in origin. The mean feed intake, free water intake and urine output also decreased following intoxication of sheep with DIN. There were increases in the plasma aspertate transferase [AST], alkaline phosphatase [ALP] and plasma creatinine post exposure to DIN. The mean values for plasma sodium, potassium and chloride concentrations showed no significant differences following intoxication with deisopropylngaione in sheep.
\end{abstract}

Key words: deisopropylngaione, intoxication, pre-renal impairment

\section{Introduction}

Following poisoning of sheep by the plant Myoporum deserti, Johnstone and Alien (1944) observed from histopathology slides considerable congestion of both kidney cortex and medulla with evidence of some toxic damage to the glomerulus and epithelial cells of the convoluted tubules of the kidneys. Riek and Wright (1946) dosed sheep with the oil obtained from Myoporum acuminatum another member of the family Myoporacae, and described widespread congestion of both kidney cortex and medullary layers together .with degenerative changes in the epithelial cells of the convoluted tubules from histopathology slides.

This paper considered the effect of deisopropylngaione, one of the twelve essential oils in the plant Myoporum deserti [figure 1] on the renal function in the sheep.

\section{Materials and methods}

The Deisopropylngaione [DIN] was obtained from the leaves of Myoporum deserti by steam distillation. A total of twelve female merino lambs weighing between $10-15 \mathrm{~kg}$ and aged 9-15 months were used in this experiment. Seven lambs were employed in the renal clearance studies while five were used to establish a dose rate sufficient to cause changes in the renal function. They were kept in fiberglass metabolism cages in an air-conditioned room maintained at 22 to $25^{\circ} \mathrm{C}$ and relative humidity of $55 \%$. Two periods -conditioning and treatment were recognizable during the experiment. During the conditioning period each lamb was accurately weighed to $0.1 \mathrm{~kg}$ body weight, ear tagged, dewormed with Fenbendazole bolus at $250 \mathrm{mg} /$ body weight and their urinary bladder were catheterized using $12 \mathrm{G} \times 5 \mathrm{ml}$ balloon Bardex silicone elastomere coated Foley catheter. This is to ensure 
that the urethra were patent. Each lamb was fed $16 \mathrm{~g}$ dry matter per $\mathrm{kg}$ body weight of Lucerne chaff daily from a single source throughout the experimental period. Aliquot samples from this feed batch were subjected to proximate analysis for moisture content, crude protein, crude fibre, total ash, nitrogen free extract; sodium, potassium and chloride ions determinations AOAC (1990). Electrolyte free water was offered ad libitum. Pre treatment blood and urine samples were collected for blood chemistry and urinalysis.

\section{Blood Chemistry:}

$10 \mathrm{ml}$ blood sample drawn from jugular vein was put in 125i.u. lithium heparin and spun down on Bachman TJ-6 centrifuge at a speed of 3,000 rounds per minute for 5 minutes. The plasma so obtained was withdrawn into a clean plastic tube using two stop Eppendorf pipette for the following determinations: (a) albumin and (b) creatinine using HarlecoUltrachem bromocresol green reaction method on I.L. Multistat III machine; (c) Blood urea concentration, and (d) aspertate transferase using Boehringer Mannheim reagent on I.L. Multistat machine, (e) bilirubin using Corning colorimeter model 252. In addition to above sodium and potassium ions were determined using the flame emission method on photometer AHS (AUST) equipment; Chloride ion by calorimetric titration method on radiometer CMT-10 chloride titrator, and total protein by Harleco-Ultrachem biuret reaction method on I.L. Multistat III machine.

\section{Urine analysis:}

$100 \mathrm{ml}$ of freshly voided urine put in clean plastics cups were examined for the following: (a) Osmolality using the vapour pressure osmometer from Wescot Inc. (b) specific gravity by refractometry on T.S. [total solid] meter (c) $\mathrm{pH}$ using Beckman expanded, scales $\mathrm{pH}$ meter. In addition, using the N-Multistix, bile salt, urobilinogen, protein ketones, glucose and bilirubin were assessed from the urine samples.

\section{The clearance techniques:}

Renal clearance $\mathrm{CI}$ and $\mathrm{CII}$ representing pre and post exposure to the toxic dose of DIN were carried out on the $5^{\text {th }}$ day $(\mathrm{CI})$ and between day the 13 th and $14^{\text {th }}$ day $(\mathrm{CII})$ from commencement of the experiment. Prior to the day of $\mathrm{CI}$, each lamb was clipped to the skin an area $20 \mathrm{~cm} \times 20 \mathrm{~cm}$ on the ventral aspect of the neck region to expose the jugular veins. A thumb tourniquet was applied at the jugular groove to establish jugular vein patency and degree of prominence. The urethral patency was also checked by passing a $12 \mathrm{G} \times 5 \mathrm{cc}$ balloon Bardex silicone elastomere coated Foley's catheter. On the $5^{\text {th }}$ day $[\mathrm{CI}]$, each experimental lamb was weighed and drenched with $25 \mathrm{ml} / \mathrm{kg}$ body weight distilled water using a clear polyvinyl stomach tube. This is to ensure that a urine flow greater than 2 $\mathrm{ml} /$ minute is obtained. They were thereafter returned to the fiberglass metabolism cages and restrained with a head halter. The delivery end of the Foleys catheter was inserted into $500 \mathrm{ml}$ plastic bottle which was secured between the lambs two hind legs by means of a gauze bandage. The left and right jugular veins were cannulated using a $15 \mathrm{G}$ Teflon Dwellcath cannulae. A baseline (Zero) $10 \mathrm{ml}$ blood and urine samples were collected. A drip set was hooked onto a 1 liter $5 \%$ dextrose bottle and connected to the cannulae. $0.5 \mathrm{uCi} / \mathrm{kg}$ body weight of sodium iothalamate iondine $125\left(\mathrm{I}^{125}\right)$ was added to the 1 liter $5 \%$ dextrose via the rubber stopper of the bottle. A fast $100 \mathrm{ml}$ from the bottle was administered to the lamb as priming dose. This was followed immediately by $8 \mathrm{mg} / \mathrm{kg}$ body weight of a $20 \%$ 
aminophippurate sodium via the injection site of the delivery tube. To the remaining $900 \mathrm{ml}$ of $5 \%$ dextrose which contained iothalamate iodine was added $2 \mathrm{mg} / \mathrm{ml}$ of $20 \%$ aminohippurate sodium via the injection from the side of the rubber stopper of the bottle. The sustaining infusion i.e. the $900 \mathrm{ml} 5 \%$ dextrose in sodium iothalamte and $2 \mathrm{mg} / \mathrm{ml}$ of $20 \%$ aminohippurate sodium was given at 18 drops per quarter of a minute. Collection of blood samples from the second cannula started one hour later. With a $10 \mathrm{ml}$ plastic syringe, $10 \mathrm{ml}$ of blood was drawn via the vacant cannula at the mid-point of every 20 minute urine collection. $8 \mathrm{ml}$ was transferred into a $10 \mathrm{ml}$ lithium heparin coated plastic tubes and mixed gently. The remaining $2 \mathrm{ml}$ was put into $5 \mathrm{ml}$ plastic tube containing fluoride oxalate powder, mixed gently for glucose determination. The $8 \mathrm{ml}$ blood samples were centrifuged and plasma withdrawn. Six consecutive blood and urine samples were collected in this manner. Plasma sample for para-amino hippurate $[\mathrm{PAH}]$ creatinine and sodium iothalamate were not diluted while urine samples were diluted as follows: iothalamate 0 ; creatinine 1:10 and PAH 1:100. On the twelfth day from commencement of the experiment, the right paralumbar fossa of each lamb was prepared as for aseptic surgery. With an $18 \mathrm{G} \mathrm{x}$ linch non-toxic pyrogen-free needle and a $5 \mathrm{ml}$ Luxblox interchangeable glass syringe experimental lambs received 150 $\mathrm{mg} / \mathrm{kg}$ body weight deisopropylngaione [DIN] intraperitoneally via the prepared site. Post exposure clearance (CII) was carried out forty-eight hours post dosing with DIN. The GFR, RPF, and the TMG were determined same as in CI as contained in the clearance technique outlined above. On completion of CII, final blood and urine samples were collected for plasma biochemistry and urinalysis; followed by euthanasia using $325 \mathrm{mg} / \mathrm{ml} / \mathrm{kg}$ body weight of pentobarbitone sodium intravenously.

\section{Analytical methods for clearances.}

The clearance of iothalamate iodine 125 (СIOT), creatinine (CCR), and tubular transport maximum for glucose CTMG) were measured by the methods adapted from Smith (1956). Radioactivity of iothalamate $\mathrm{I}^{125}$ in plasma and urine samples was counted on Packard Autogamma scintillation spectrometer 5230. Four separate counts were made and their averages were taken. P-aminohippuric acid concentrations in both plasma and urine samples were determined by the method of Harvey and Brothers (1962) on a first generation semi automatic analyzer.

Plasma urine creatinine concentrations were determined by Jaffe Reaction using HarlecoUltrchem kit on I.L. Multistat III machine. Blood and urine glucose were assessed by the Glucose Hexokinase U.V. method using Boehringer-Mannheim reagent kit No. 124346 on I.L Multistat III machine.

\section{Results}

\section{The renal clearance:}

The changes in the mean values for the clearances of sodium iothalamate iodine 125 (Ciot) representing the glomerular filtration rate (GFR), the p-aminohippuric acid (CPAH) representing the renal plasma flow (RPF), the tubular transport maximum for glucose (TMG) and the filtration fraction percentages $(\mathrm{FF} \%=\mathrm{GFR} / \mathrm{RPF})$ were outlined in Table 1 . 
Table 1: Mean Values of the Glomerular Filtration Rate [GFRj, Renal Plasma Flow [RPF] Filtration Fraction Percent [FFP] and Tubular Transport Maximum for Glucose [TMG] Before and 48hurs Following Intoxication with $150 \mathrm{mgkg}$ Weight Deisopropylngione in Sheep.

\begin{tabular}{|c|c|c|c|c|c|c|}
\hline $\begin{array}{l}\text { Sheep } \\
\text { No. }\end{array}$ & $\begin{array}{l}\text { Body weight } \\
(\mathrm{Kg})\end{array}$ & $\begin{array}{l}\text { Urine } \\
\text { Flow } \\
(\mathrm{ml} / \mathrm{min})\end{array}$ & $\begin{array}{l}\text { GFR(CIOT) } \\
(\mathrm{ml} / \mathrm{min} / \mathrm{kg} \\
\text { Body } \\
\text { weight) }\end{array}$ & $\begin{array}{l}\text { RPF } \\
(\mathrm{ml} / \mathrm{min} / \mathrm{kg} \\
\text { Body } \\
\text { weight })\end{array}$ & FF $(\%)$ & $\begin{array}{l}\text { TmG } \\
\text { (umol } / \mathrm{min} / \mathrm{kg} \\
\text { Body weight) }\end{array}$ \\
\hline 121 & $\begin{array}{l}12.9 \\
12.5\end{array}$ & $\begin{array}{l}3.9 \\
2.6\end{array}$ & $\begin{array}{l}2.81 \\
1.53\end{array}$ & $\begin{array}{l}15.41 \\
2.01\end{array}$ & $\begin{array}{l}18.42 \\
76.74\end{array}$ & $\begin{array}{l}25 \\
9\end{array}$ \\
\hline 53 & 15.815 .8 & 4.81 .6 & 2.351 .57 & 13.541 .22 & $\begin{array}{l}17.47 \\
127.65\end{array}$ & 2719 \\
\hline 128 & 14.414 .4 & $\begin{array}{l}3.6 \\
3.5\end{array}$ & 2.822 .39 & 15.4715 .56 & $\begin{array}{l}18.17 \\
18.52\end{array}$ & 2227 \\
\hline 122 & 13.713 .2 & 3.73 .1 & $\begin{array}{l}2.44 \\
2.32\end{array}$ & 17.7714 .71 & $\begin{array}{l}13.75 \\
15.86\end{array}$ & $\begin{array}{l}36 \\
32\end{array}$ \\
\hline 124 & 15.115 .4 & 5.04 .0 & 2.001 .96 & 14.3114 .11 & $\begin{array}{l}14.08 \\
12.19\end{array}$ & $\begin{array}{l}19 \\
13\end{array}$ \\
\hline $126^{* \prime}$ & 14.9 & 3.9 & 2.57 & 14.36 & 17,99 & 28 \\
\hline 856 & $\begin{array}{l}15.2 \\
15.6\end{array}$ & $\begin{array}{l}4.0 \\
3.4\end{array}$ & $\begin{array}{l}2.91 \\
1.44\end{array}$ & $\begin{array}{l}13.02 \\
2.15\end{array}$ & $\begin{array}{l}22.62 \\
85.00\end{array}$ & $\begin{array}{l}40 \\
25\end{array}$ \\
\hline
\end{tabular}

Top row values represent pre dosing [Before] and bottom row values represent post dosing [After].

Post exposure to DIN resulted in significant decreases in urine flow in sheep 53 from $4.8 \mathrm{ml} / \mathrm{min}$ pre dosing to $1.6 \mathrm{ml} / \mathrm{min}$ post dosing; and in sheep $121 \mathrm{form} 3.9 \mathrm{ml} / \mathrm{min}$ to $2.6 \mathrm{ml} / \mathrm{min}$. Significant decreases were also seen in the RPF where in sheep 121 it dropped from $15.4 \mathrm{ml} / \mathrm{min} / \mathrm{kg}$ body weight pre dosing to $2 \mathrm{ml} / \mathrm{min} / \mathrm{kg}$ body weight post exposure to DIN. In sheep 53, RPF decreased from $13.5 \mathrm{ml} / \mathrm{min} / \mathrm{kg}$ body weight to $1.2 \mathrm{ml} / \mathrm{min} / \mathrm{kg}$ body weight post dosing. Consequently, the filtration fraction increased from $18.4 \%$ pre exposure to $76.7 \%$ in sheep 121 ; while in sheep $55 \mathrm{FF} \%$ went up from $17.4 \%$ to $127.7 \%$. There were no significant changes for the tubular transport maximum for glucose. Sheep 126 was lost soon after intoxication with DIN and hence there was no post dosing clearance for her. Post mortem examination revealed extensive pulmonary oedema. In sheep 856 the GFR decreased from $2.9 \mathrm{ml} / \mathrm{min} / \mathrm{kg}$ body weight to $1.4 \mathrm{ml} / \mathrm{min} / \mathrm{kg}$ body weight post exposure; the 
RPF dropped from $13 \mathrm{ml} / \mathrm{min} / \mathrm{kg}$ body weight pre dosing to $2.2 \mathrm{ml} / \mathrm{min} / \mathrm{kg}$ body weight post exposure while the filtration fraction increased from $22.6 \%$ to $85 \%$ post dosing.

Table 2: Mean values of feed intake, free water intake, urine output analysis prior to and 48 hours following intoxication of sheep with $150 \mathrm{nig} / \mathrm{kg}$ body weight

Deisopropylngalone.

\begin{tabular}{|c|c|c|c|c|c|c|c|}
\hline \multirow{4}{*}{$\begin{array}{l}\text { Sheep } \\
\text { No. }\end{array}$} & \multirow{4}{*}{$\begin{array}{l}\text { Feed intake }[\mathrm{g} / \mathrm{kg} \\
\text { body weight }]\end{array}$} & \multirow{4}{*}{$\begin{array}{l}\text { Free } \\
\text { Water } \\
\text { intake } \\
\text { (ml/body } \\
\text { wt./day) }\end{array}$} & \multirow{4}{*}{$\begin{array}{l}\text { Urine } \\
\text { Output } \\
(\mathrm{ml} / \mathrm{kg})\end{array}$} & \multicolumn{4}{|c|}{ Urine Analysis } \\
\hline & & & & & & & \\
\hline & & & & \multicolumn{4}{|c|}{ Electrolytes $\mathrm{mm} / \mathrm{kg} /$ day } \\
\hline & & & & SG & $\mathrm{Na}^{+}$ & $\mathrm{K}^{+}$ & $\mathrm{Cl}-$ \\
\hline 121 & 18.7618 .76 & 75.644 .8 & 44.914 .9 & $\begin{array}{l}1.019 \\
1.022\end{array}$ & 109 & $\begin{array}{l}186 \\
108\end{array}$ & 143121 \\
\hline 53 & 18.6618 .75 & 59.228 .5 & 18.412 .6 & $\begin{array}{l}1.033 \\
1.029\end{array}$ & 4036 & $\begin{array}{l}280 \\
288\end{array}$ & 289280 \\
\hline 128 & $\begin{array}{l}18.80 \\
18.27\end{array}$ & 55.448 .7 & 27.423 .3 & $\begin{array}{l}1.025 \\
1.017\end{array}$ & 2237 & $\begin{array}{l}235 \\
411\end{array}$ & $\begin{array}{l}160 \\
72\end{array}$ \\
\hline 122 & 18.8018 .80 & 104.198 .5 & \begin{tabular}{|l}
91.1 \\
43.5
\end{tabular} & $\begin{array}{l}1.009 \\
1.016\end{array}$ & $\begin{array}{l}8 \\
3\end{array}$ & 9697 & 6849 \\
\hline 124 & 18.6018 .40 & 65.560 .7 & 34.138 .3 & $\begin{array}{l}1.029 \\
1.024\end{array}$ & 2264 & $\begin{array}{l}214 \\
258\end{array}$ & 208207 \\
\hline 126 & 18.40 & 89.1 & 53.2 & 1.009 & 36 & 145 & 208 \\
\hline 856 & $\begin{array}{l}18.60 \\
18.80\end{array}$ & $\begin{array}{l}74.6 \\
32.4\end{array}$ & $\begin{array}{l}61.0 \\
44.4\end{array}$ & $\begin{array}{l}1.035 \\
1.033\end{array}$ & 25 & $\begin{array}{l}175 \\
170\end{array}$ & $\begin{array}{l}150 \\
135\end{array}$ \\
\hline
\end{tabular}

Top row values represent pre dosing [Before] and bottom row values represent post dosing [After]. Key: S.G - Specific Gravity $\mathrm{Na}^{+} \quad$ - Sodium ion

K - Potassium ion

$\mathrm{Cl}$ - - Chloride ion

Table 2 outlined the daily mean values of feed and water intakes and urine analysis before and after single $150 \mathrm{mg} / \mathrm{kg}$ of DIN to sheep. In sheep 128 the feed intake decreased from $18.8 \mathrm{~g} / \mathrm{kg}$ body weight to $11.3 \mathrm{~g} / \mathrm{kg}$ post dosing. Likewise, there was decrease in feed intake in 
Table 3. Mean values of the plasma biochemistry prior to and 48 hours

following administration of $150 \mathrm{mg} / \mathrm{kg}$ body weight deisopropylngaine to sheep.

\begin{tabular}{|c|c|c|c|c|c|c|c|c|c|}
\hline \multirow[t]{3}{*}{ Sheep No } & \multirow{3}{*}{$\begin{array}{l}\text { BUN } \\
{[\mathrm{mmol} / \mathrm{L}]}\end{array}$} & \multirow{3}{*}{$\begin{array}{l}\text { Creatinine } \\
\text { [lj.mol/L] }\end{array}$} & \multirow{3}{*}{$\begin{array}{l}\text { AST } \\
\text { U/L }\end{array}$} & \multirow{3}{*}{$\begin{array}{l}\text { ALK.PHOS. } \\
\text { U/L }\end{array}$} & \multicolumn{5}{|c|}{ Urine Analysis } \\
\hline & & & & & \multicolumn{3}{|c|}{$\begin{array}{l}\text { Electrolytes } \\
\mathrm{mmol} / \mathrm{kg} / \text { day }\end{array}$} & \multicolumn{2}{|c|}{ Protein $[\mathrm{g} / \mathrm{L}]$} \\
\hline & & & & & $\mathrm{Na}^{+}$ & $\mathrm{K}^{+}$ & $\mathrm{Cr}$ & Total & Albumin \\
\hline 121 & 9.359 .70 & 70100 & 28456 & 5387 & $\begin{array}{l}138 \\
151\end{array}$ & 4.93 .1 & $\begin{array}{l}96 \\
97\end{array}$ & $\begin{array}{l}59 \\
51\end{array}$ & 3421 \\
\hline 53 & 9.039 .65 & 92121 & $\begin{array}{l}29 \\
435\end{array}$ & $\begin{array}{l}18 \\
32\end{array}$ & 142155 & 4.54 .1 & $\begin{array}{l}134 \\
131\end{array}$ & $\begin{array}{l}60 \\
52\end{array}$ & 3433 \\
\hline 128 & 8.66 .3 & 7380 & 30128 & $\begin{array}{l}50 \\
57\end{array}$ & 139143 & 5.04 .7 & 8995 & 6165 & 3433 \\
\hline 122 & $\begin{array}{l}8.7 \\
4.1\end{array}$ & $\begin{array}{l}138 \\
355\end{array}$ & $\begin{array}{l}43 \\
965\end{array}$ & $\begin{array}{l}13 \\
49\end{array}$ & $\begin{array}{l}143 \\
152\end{array}$ & $\begin{array}{l}3.8 \\
4.0\end{array}$ & $\begin{array}{l}106 \\
107\end{array}$ & $\begin{array}{l}59 \\
52\end{array}$ & $\begin{array}{l}38 \\
30\end{array}$ \\
\hline 124 & 11.29 .1 & $\begin{array}{l}95 \\
78\end{array}$ & 31591 & 1753 & 142141 & 4.74 .2 & $\begin{array}{l}104 \\
105\end{array}$ & 6462 & 3533 \\
\hline 126 & 10.5 & 81 & 46 & 56 & 142 & 4.2 & 94 & 65 & 36 \\
\hline $856^{\prime \prime}$ & $\begin{array}{l}8.8 \\
9.6\end{array}$ & $\begin{array}{l}95 \\
280\end{array}$ & $\begin{array}{l}55 \\
65\end{array}$ & $\begin{array}{l}23 \\
30\end{array}$ & $\begin{array}{l}143 \\
144\end{array}$ & $\begin{array}{l}4.3 \\
4.6\end{array}$ & $\begin{array}{l}104 \\
109\end{array}$ & $\begin{array}{l}54 \\
46\end{array}$ & $\begin{array}{l}34 \\
28\end{array}$ \\
\hline
\end{tabular}

Top row values represents pre dosing [Before] and bottom row values represents post dosing [After].

Key: BUN - Blood Urea Nitrogen

AST - Aspertate Transferase

ALK.PHOS. - Alkaline Phosphatase

sheep 124 from $18.6 \mathrm{~g} / \mathrm{kg}$ to $8.4 \mathrm{~g} / \mathrm{kg}$. Consequently, the free water intake for sheep 121 and 122 decreased significantly from $75.6 \mathrm{ml} / \mathrm{kg}$ body weight to $44.8 \mathrm{ml} / \mathrm{kg}$ and from $104.1 \mathrm{ml} / \mathrm{kg}$ to $98.5 \mathrm{ml} / \mathrm{kg}$ post dosing respectively. Urine outputs were also affected especially in sheep 121 and 122 . In sheep 121 urine output decreased from $44.9 \mathrm{ml} / \mathrm{kg}$ body weight to $14.9 \mathrm{ml} / \mathrm{kg}$ post exposure to DIN and in sheep 122 from $91.1 \mathrm{ml} / \mathrm{kg}$ to $43.5 \mathrm{ml} / \mathrm{kg}$ body weight. In sheep 856 free water in take decreased from $74.6 \mathrm{ml} / \mathrm{bw} /$ day pre dosing to $32.4 \mathrm{ml} / \mathrm{bw} /$ day post dosing, and the urine output decreased from $61 \mathrm{ml} / \mathrm{ml} / \mathrm{kg}$ to $44.4 \mathrm{ml} / \mathrm{kg}$ post dosing. There were no significant changes in the urine specific gravity. However, there were slight changes in the urine electrolytes. For instance in sheep 128 urine sodium ion $(\mathrm{Na})$ increased from $22 \mathrm{mmol} / \mathrm{kg} /$ day to $37 \mathrm{mmol} / \mathrm{kg}$ /day post exposure to DIN; and in sheep 124 from $22 \mathrm{mmol} / \mathrm{kg} /$ day to $64 \mathrm{mmol} / \mathrm{kg} / \mathrm{day}$. The chloride ion $\left(\mathrm{Cl}^{-} \mathrm{w}\right)$ decreased from 
$160 \mathrm{mmol} / \mathrm{kg}$ /day to $72 \mathrm{mmol} / \mathrm{kg} /$ day in sheep 128 ; while in sheep $122 \mathrm{Cl}^{-}$decreased from $68.5 \mathrm{mmol} / \mathrm{kg} /$ day to $49 \mathrm{mmol} / \mathrm{kg} /$ day post exposure to DIN.

There were changes in the blood urea nitrogen, creatinine, aspertate transferase and alkaline phosphatase. For instance, in sheep 121 , creatinine increased from $70 \mathrm{umol} / \mathrm{L}$ pre dosing to $100 \mathrm{umol} / \mathrm{L}$ post dosing and in sheep $122 \mathrm{from} 137.5 \mathrm{umol} / \mathrm{L}$ to $354 \mathrm{umol} / \mathrm{L}$. In sheep 121 the aspertate transferase (AST) increased from $27.5 \mu / \mathrm{L}$ pre dosing to $456 \mu / \mathrm{L}$ post dosing while in sheep 128 the AST went up from $30 \mu / \mathrm{L}$ to $128 \mu / \mathrm{L} ; 42.8 \mu / \mathrm{L}$ to $964 \mu / \mathrm{L}$ in sheep 122 ; and in sheep 124 the AST shot up from $31 \mu / \mathrm{L}$ pre dosing to $591.7 \mathrm{U} / \mathrm{L}$ post dosing. Significant changes were also recorded for the serum alkaline phosphatase (ALP). In sheep 121 ALP rose from $53 \mu / \mathrm{L}$ to $87 \mu / \mathrm{L}$; from $12.7 \mu / \mathrm{L}$ to $48.5 \mu / \mathrm{L}$ in sheep 122 and $17 \mu / \mathrm{L}$ to $52.7 \mu / \mathrm{L}$ in sheep 124.

\section{Discussion}

In comparing measurements of renal function before intoxication of sheep with deisopropylngaione (DIN) it was assumed that in the normal sheep each kidney contained approximately the same number of nephrons that contribute equally to the total function. The decreases in the urine flow and renal plasma flow coupled with the drop in the glomerular filtration rate following intoxication of sheep with DIN could have been precipitated by non-renal conditions encountered in the course of the experiment such as increase in the plasma aspertate transferase and alkaline phosphatase both indicating liver dysfunction. Lowenstein et al (1961) demonstrated a systematic decrease in GFR, RPF and TMG with increase in age. Young lambs (9-15 months) were used in this experiment with the expectation that the microsomal mixed function oxidase system is at its optimum Functioning capacity. Hence the decreases in the GFR seen in this experiment could not have been due to age but probably due to intoxication by DIN. Horster and Levy (1970) demonstrated a decrease in the RPF and rise in FF\% during the neonatal period in rat in which renal function is disturbed by non-renal diseases which in turn resulted to pre-renal failure. Hepatic cirrhosis ranks high among non-renal diseases and it is characterized by profound metabolic disturbances leading to hypoproteinemia and subsequent formation of oedema, Seawright and Hrdlicka (1978). It was stated in the result portion of this paper that pulmonary oedema may have contributed to the death of sheep 856 from post mortem examination following intoxication by DIN. It can therefore be inferred that the increases in AST and ALP (Liver function tests, Benjamin, 1970) seen following intoxication with DIN are indeed as a result of liver injury in the sheep so intoxicated. When compared with the specific kidney lesions and decreased renal function in the absence of non-renal diseases or conditions seen in mercuric chloride poisoning in sheep Berling (1963) and Berling and Ulberg (1963) we conclude that the reduction in the renal function based on decreases in the GFR, RPF and urine flow seen in lamb*: intoxicated by DIN was in the main pre renal in origin

\section{References}

1. Johnstone, I.L., and Alien, G.H. (1944). Observations on the Poisoning of Sheep by Myoporum deserti [Turkey Bush or Ellangowan Bush]. Aust. Vet. J., 20:227-230.

2. Reik, R.F. and Wright, S.E. (1946). The Toxic Properties of the Volatile Oil of Myoporum acuminatum. Aust. Vet. J. 22; 149-153. 
3. AOAC (1990). Association of Official Analytical Chemist. Official methods of Analysis ( $5^{\text {th }}$ ed) Vol.1 Arlington, Virginia

4. Smith, H.C, Taussig,R.A, and Peterson, P.C;(1956): Deadly Nightshade poisoning in swine. J.Am.Vet.Med. Assn, 129:116-117.

5. Harvey, R.B. and Brothers, A.J.(1962):The kidneys and the internal environtment. Ann.N.Y.Acd.Sci. pp 260.

6. Lowenstein, J., Faulstick, D.A., Yiengst, M.J. and Shock, N.W. (1961). The Glomerular Clearance and Renal Transport of Haemoglobin in Adult Males. J. Clin. Invest., 40: 1172-1177.

7. Horster, M., and Lewy, I.E. (1970). Filtration Fraction and Extraction of PAH During Neonatal Period in the Rat. Am. J. Physiol, 219(4): 1061-1065.

8. Seawright, A.A. and Hrdlicka, J. (1978). The Effect of Prior Dosing with Phenobarbitone and pDiethylaminoethyl Diphenylpropyl Acetate [SKF 525A] on the Toxicity and Liver Lesion Caused by ngaione in the Mouse. Brit. J. Exp. Path. 53:242-252.

9. Benjamin, M.M. (1970). Outline of Veterinary Clinical Pathology, $2^{\text {nd }}$ Edition. The Iowa State University Press, Ames, Iowa USA, pp 122-123.

10. Berlin, M. (1963). Renal Uptake, Excretion and Retention of Mercury II. A study in the rabbit during infusion of Methyl and Phenyl mercuric Compounds. Archives of Environmental Health. 6: 626-633.

11. Berlin, M., and Ullberg, S. (1963). Accumulation and Retention of Mercury in the Mouse. An Auto radiographic Study after a single Intravenous Injection of Mercuric Chloride. Archives of Environmental Health. 6:589-601. 